JOURNAL OF ENGINEERING SCIENCES

ЖУРНАЛ ІНЖЕНЕРНИХ НАУК

ЖУРНАЛ ИНЖЕНЕРНЫХ НАУК

Web site: http://jes.sumdu.edu.ua

DOI: 10.21272/jes.2019.6(2).f2

Volume 6, Issue 2 (2019)

\title{
General Features of the Metallic Corrosion in Raw Crude Oils
}

\author{
Aluvihara S. ${ }^{1 *}$, Premachandra J. K. ${ }^{2}$ \\ ${ }^{1}$ Department of Chemical and Process Engineering, University of Peradeniya, 20400 Peradeniya, Sri Lanka; \\ ${ }^{2}$ Department of Chemical and Process Engineering, University of Moratuwa, 10400 Katubedda, Sri Lanka
}

\section{Article info:}

Paper received:

The final version of the paper received:

Paper accepted online:
April 2, 2019

June 12, 2019

June 17, 2019
*Corresponding Author's Address:

sureshaluvihare@gmail.com

\begin{abstract}
Raw crude oils are mainly composed of various hydrocarbons while having trace amounts of corrosive compounds such as sulphur compounds, naphthenic acids, and salts. In the existing research, there were expected to investigate the impact of such corrosive properties on the corrosion of seven different types of ferrous metals. As the methodology, the major corrosive properties of selected two different types of crude oils and the chemical compositions of seven selected metal types were measured and analyzed by the standard methodologies and recommend instruments. The corrosion rates of such metals were determined by the relative weight loss method after certain immersion time periods simultaneously with the microscopic analysis of corroded metal surfaces. In addition, the decayed metallic elemental concentrations from metals into crude oils were analyzed by the atomic absorption spectroscopy (AAS) and the impact of the corrosion on the initial hardness of metals were measured by the Vickers hardness tester. As the results and outcomes of the entire research that there observed relatively lower corrosion rates from stainless steels with at least $12 \%$ of chromium and some amount of nickel, higher corrosive impact from salts on the metallic corrosion, formations of $\mathrm{FeS}, \mathrm{Fe}_{2} \mathrm{O}_{3}$, corrosion cracks and pitting on the metal surfaces, decay of copper and ferrous from some of metals sometimes in significantly and small reductions of the initial hardness of most of metals due to the corrosion.
\end{abstract}

Keywords: raw crude oils, corrosive compounds, metals, weight loss, decay, corrosion.

\section{Introduction}

Raw crude oils are dominant earth resources that found from the interior part of the earth that mostly composed with various hydrocarbons since having less amounts of some other compounds foremost of the corrosive compounds [1-6]. According to the explanations of the phenomenon of corrosion it is usually defined as the formations of the relevant metal sulfides, oxides or hydroxides on the metal surface as the result of either chemical or electrochemical reaction on the metallic surfaces due to the interactions of such metals either with some strong oxidizing chemical compound or any system which is composed with both water and oxygen. The corrosion process may be quietly different with the conditions of such corrosive compounds or the supportive conditions such as the temperature [4-15].

According to the recently performed experiments and literature reviews of the chemical engineering concepts that there were speculated some significant impact from various sulfur compounds such as sulfoxides, thiophenes, hydrogen sulfides and also elemental sulfur in the most of investigations under different conditions and the impact of salts and organic acids also play a dominant background in the metallic corrosion [6-15].

In the existing research mainly, there were expected to analyze the impact of elemental sulfur, Mercaptans, organic acids and salts of different types of selected crude oils on the corrosion of seven different types of selected ferrous metals which are widely used in the industry of crude oils refining. The investigations were based on both qualitatively and quantitatively analysis of the corrosion.

\section{Research Methodology}

According to the availability and the requirements of the existing research two different types of crude oils were selected for the experiments which are slightly different in their chemical compositions including corrosive composites. Those are namely as Murban and Das Blend also with the sulfur content Das Blend may have higher amount of sulfur which is an important factor for the corrosion. The elemental sulfur contents, Mercaptans contents, organic acid contents and salt contents of both crude oils were measured by the standard methods and instruments as explained in Table 1. 
Table 1 - Analysis of the corrosive properties of crude oils

\begin{tabular}{|l|l|l|}
\hline \multicolumn{1}{|c|}{ Property } & \multicolumn{1}{|c|}{ Method } & Readings \\
\hline Sulfur content & $\begin{array}{l}\text { Directly used the crude oil } \\
\text { samples to the XRF analyz- } \\
\text { er }\end{array}$ & $\begin{array}{l}\text { Direct } \\
\text { reading }\end{array}$ \\
\hline Acidity & $\begin{array}{l}\text { Each sample was dissolved } \\
\text { in a mixture of toluene and } \\
\text { isopropyl and titrated with } \\
\text { potassium hydroxide }\end{array}$ & End point \\
\hline $\begin{array}{l}\text { Mercaptans } \\
\text { content }\end{array}$ & $\begin{array}{l}\text { Each sample was dissolved } \\
\text { in sodium acetate and titrat- } \\
\text { ed with silver nitrate }\end{array}$ & End point \\
\hline Salt content & $\begin{array}{l}\text { Each sample was dissolved } \\
\text { in organic solvent and ex- } \\
\text { posed to the cell of analyzer }\end{array}$ & $\begin{array}{l}\text { Direct } \\
\text { reading }\end{array}$ \\
\hline
\end{tabular}

By considering the applicability of the metals in the industry of crude oil refining and the variability of the chemical compositions of such metals seven different types of metals were selected as the corrosion determination samples. The selected metals and some of their applications are given in the below:

- carbon steel (high) - transportation tubes, storage tanks;

-carbon steel (medium) - storage tanks, transportation tubes;

- carbon steel (mild steel) - storage tanks;

-410-MN: 1.8 420-MN: 2.8 (stainless steel) - heat exchangers, pre-heaters;

- 410-MN: 1.7 420-MN: 1.7 (stainless steel) - crude distillation columns, pre-heaters;

- 321-MN: 1.4 304-MN: 1.9 (stainless steel) - crude distillation columns;

- Monel 400 - pre-heaters, heat exchangers, desalting units.

The chemical compositions of such metals were tested by the X-ray fluorescence detector. A batch of similar sized metal coupons was prepared from such metal types and the surfaces of such metal coupons were cleaned by the isooctane and sand papers. The initial weight and the dimensions of such metal coupons were measured by in order of analytical balance and micrometer. The prepared metal coupons have been shown in Figure 1.

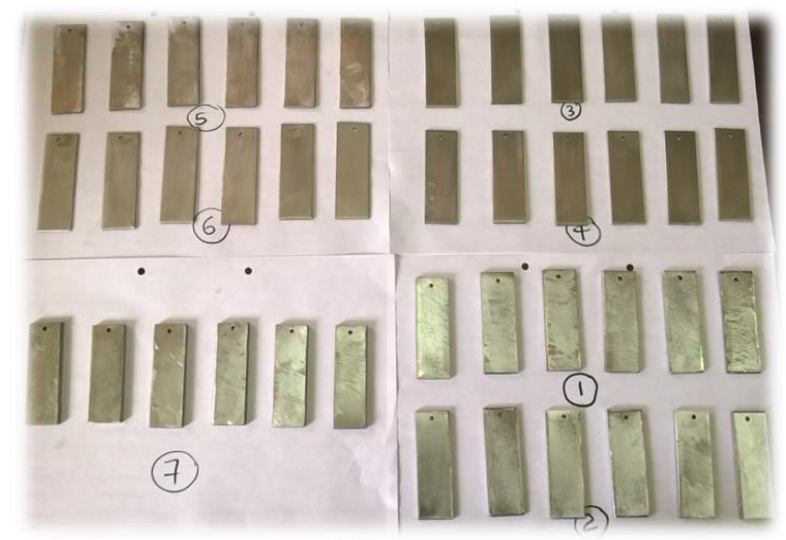

Figure 1 - Prepared metal coupons for the experiment
The prepared metal coupons were immersed in beakers which are filled with crude oils as three homogeneous metal coupons in each crude oil container.

After 15 days immersion time period one metal coupon from each crude oil container was taken out and the corroded metal surfaces were observed through 400X lens of an optical microscope. The corroded metal surfaces of such metal coupons were cleaned by the isooctane and sand papers, and the final weight of each metal coupon was measured by the analytical balance based on the determinations of the corrosion rate of each metal coupon by the weight loss method as discussed in the below $[9,10]$ :

$$
C R=W \cdot k /(D \cdot A \cdot t),
$$

where $C R$ - corrosion rate of metal piece; $W$ - weight loss due to the corrosion, g; $k=22.3$ - constant; $D$ - metal density, $\mathrm{g} / \mathrm{cm}^{3} ; A-$ area of metal piece, inch ${ }^{2}$; $t$ - time, days.

By following the same methodology, the corrosion rates of another two similar sets of metal coupons were determined in order of after 30 and 45 days from the immersion including each analysis stage that mentioned for the first set of metal coupons.

In addition to the basic analysis the decayed metallic concentrations from each metal while the immersion in crude oil samples were tested by the atomic absorption spectroscopy (AAS). The actual reason for this investigation was the observed invisible weight loss of some metals during the determinations of the corrosion rates of metals. In the sample preparation $1 \mathrm{ml}$ of each crude oil sample was diluted with $9 \mathrm{ml}$ of 2-propanol and filtered.

As the last experiment of the current research the variations of the initial hardness of metal coupons after the corrosion were measured by the Vickers hardness tester. The working theories of such instruments have been applied using the following equation:

$$
H V=1.854 \cdot(P / L)^{2},
$$

where $H V$ - hardness; $P$ - applied Load on the surface of metal; $L$ - diagonal length of a square.

As the essential measurements the initial hardness and hardness after the corrosion of metal coupons were measured by such instrument. By considering the accuracy the hardness of at least three positions on the metal coupons were measured for on measurement.

\section{Results and Discussion}

The basic results for the analysis of the chemical compositions of the selected ferrous metals have been given in Table 2.

According to the above results it can be obtained some higher ferrous contents in carbon steels, moderate ferrous contents in stainless steels and trace ferrous concentrations in Monel metal. Beside of that there were observed some trace compositions of d-block elements such as nickel, copper and chromium especially in stainless steels because of the aims and objectives of the enhancements 
of the strength and corrosive reduction method. Because the combination of the chromium and nickel is a good buffer for the corrosion on the metal surfaces itself when having at least $12 \%$ of chromium and sufficient amount of nickel [1, 3-6].

Table 2 - Chemical compositions of metals, $\%$

\begin{tabular}{|l|c|c|c|c|}
\hline \multicolumn{1}{|c|}{ Metal } & $\mathrm{Fe}$ & $\mathrm{Ni}$ & $\mathrm{Cr}$ & $\mathrm{Cu}$ \\
\hline $\begin{array}{l}\text { carbon steel } \\
\text { (high) }\end{array}$ & 98.60 & 0.17 & 0.14 & 0.37 \\
\hline $\begin{array}{l}\text { carbon steel } \\
\text { (medium) }\end{array}$ & 99.36 & - & - & - \\
\hline $\begin{array}{l}\text { carbon steel } \\
\text { (mild steel) }\end{array}$ & 99.46 & - & $<0.07$ & - \\
\hline $\begin{array}{l}\text { 410-MN: } 1.8 \\
\text { 420-MN: } 2.8 \\
\text { (stainless } \\
\text { steel) }\end{array}$ & 88.25 & 0.18 & 10.92 & 0.10 \\
\hline $\begin{array}{l}\text { 410-MN: } 1.7 \\
\text { 420-MN: } 1.7 \\
\text { (stainless } \\
\text { steel) }\end{array}$ & 87.44 & - & 11.99 & - \\
\hline $\begin{array}{l}\text { 321-MN:1.4 } \\
\text { 304-MN:1.9 } \\
\text { (stainless } \\
\text { steel) }\end{array}$ & 72.47 & 8.65 & 17.14 & - \\
\hline Monel 400 & 1.40 & 64.36 & $<0.04$ & 33.29 \\
\hline
\end{tabular}

According to the analysis of the corrosive compounds of both crude oils the obtained results have been shortlisted in Table 3.

Table 3 - Corrosive properties of crude oils

\begin{tabular}{|l|c|c|}
\hline \multicolumn{1}{|c|}{ Property } & Murban & Das Blend \\
\hline sulfur content, Wt. \% & 0.758 & 1.135 \\
\hline salt content, ptb & 4.4 & 3.6 \\
\hline acidity, mg KOH/g & 0.01 & 0.02 \\
\hline Mercaptans content, ppm & 25 & 56 \\
\hline
\end{tabular}

After referring above numerical values that it is possible to conclude the Das Blend crude oil may have higher corrosive tendency because the above results show higher elemental sulfur content, Mercaptans content, organic acid content and lower salt content in Das Blend crude oils when comparing with Murban crude oil. But, the corrosive impact of some crude oil cannot be estimated only considering the magnitudes of the concentrations of the corrosive compounds in crude oils and it must be considered the supporting conditions for the happening of relevant chemical reactions as well. It has been discussed in ahead with the obtained results in the existing research.

Organic acids are the dominant corrosive compounds presence in most of crude oils since the occurrences because of the abundance of different organic acids in the early living organisms. Such organic acid is also known as naphthenic acids which are having the chemical formula of "RCOOH" and the total amount of organic or naphthenic acids of some crude oil is known as the acidity or total acid number (TAN) of such crude oil. The general chemical reactions of the oxidizing process of organic acids are given in the below $[2,4,9,12,13,15]$ :

$$
\begin{gathered}
\mathrm{Fe}+2 \mathrm{RCOOH} \rightarrow \mathrm{Fe}(\mathrm{RCOO}) 2+\mathrm{H} 2 \\
\mathrm{FeS}+2 \mathrm{RCOOH} \rightarrow \mathrm{Fe}(\mathrm{COOR})_{2}+\mathrm{H}_{2} \mathrm{~S} \\
\mathrm{Fe}(\mathrm{COOR}) 2+\mathrm{H} 2 \mathrm{~S} \rightarrow \mathrm{FeS}+2 \mathrm{RCOOH} .
\end{gathered}
$$

Salts are the foremost corrosive compounds find from crude oils since the occurrences mainly as the forms of $\mathrm{NaCl}, \mathrm{MgCl}_{2}$ and $\mathrm{CaCl}_{2}$. The total amount of such salts presence in some crude oil is known as the salt content of such crude oil. When increasing the temperature of crude oils such salts tend to be broken into $\mathrm{HCl}$ molecules which are inert in the same conditions. When decreasing the temperature of the system such $\mathrm{HCl}$ molecules tend to be reacted with water of even moisture and formed highly corrosive hydrochloric acids. The general chemical reactions between the salts and metals have been given in the following equations $[2,4,7,11]$.

$$
\begin{gathered}
\mathrm{CaCl}_{2}+\mathrm{H}_{2} \mathrm{O} \rightarrow \mathrm{CaO}+2 \mathrm{HCl} \\
\mathrm{HCl}+\mathrm{Fe} \rightarrow \mathrm{FeCl}_{2}+2 \mathrm{H}_{2} \\
\mathrm{H} 2+\mathrm{S} \rightarrow \mathrm{H}_{2} \mathrm{~S} \\
\mathrm{FeCl}_{2}+\mathrm{H}_{2} \mathrm{~S} \rightarrow \mathrm{FeS}+2 \mathrm{HCl}
\end{gathered}
$$

Sulfur compounds are some sort of corrosive compounds because of the availability of wide range of various active sulfur compounds with the highly volatile functional groups. Among sulfur compounds most of them are corrosive compounds such as elemental sulfur, Mercaptans, sulfoxides and thiophenes. Mercaptans are highly corrosive compounds which are having a molecular formula of "RSH" because of the high reactivity of relevant functional group. The corrosion reactions may be differing with the behaviors of such corrosive compounds $[4,14]$. The corrosion process due to the elemental sulfur is known as the "localized corrosion" which is usually happened at the temperature $80{ }^{\circ} \mathrm{C}$ properly.

Additionally, the corrosion process due to the Mercaptans is known as the "sulfidation" which is likely to be happened at about $230{ }^{\circ} \mathrm{C}$ properly. The initiation chemical reactions of such corrosion processes have been given in the flowing reactions $[2,4,11,13,14]$ :

$$
\begin{gathered}
\mathrm{S} 8(\mathrm{~s})+8 \mathrm{H}_{2} \mathrm{O}(\mathrm{l}) \rightarrow 6 \mathrm{H}_{2} \mathrm{~S}(\mathrm{aq})+2 \mathrm{H}_{2} \mathrm{SO}_{4}(\mathrm{aq}) \\
8 \mathrm{Fe}+\mathrm{S} 8 \rightarrow 8 \mathrm{FeS} .
\end{gathered}
$$

Altogether the impact of such corrosive properties on the metallic corrosion it is mandatory to mention about the required supporting conditions when analyzing the impact of such corrosive compounds. According to the determinations of the corrosion rates of metals by the weight loss method the obtained results have been interpreted with respect to the immersion time periods in Tables 4,5 . 
Table 4 - Corrosion rates of metals in Murban, $\mathrm{cm}^{3} /($ inch $\cdot$ day)

\begin{tabular}{|l|c|c|c|c|}
\hline \multirow{2}{*}{ Metal } & \multicolumn{3}{|c|}{ Number of days } & \multirow{2}{*}{ Average } \\
\cline { 2 - 4 } & 15 & 30 & 45 & \\
\hline $\begin{array}{l}\text { carbon steel } \\
\text { (high) }\end{array}$ & 0.812 & 0.466 & 0.069 & 0.449 \\
\hline $\begin{array}{l}\text { carbon steel } \\
\text { (medium) }\end{array}$ & 0.818 & 0.180 & 0.073 & 0.357 \\
\hline $\begin{array}{l}\text { carbon steel } \\
\text { (mild steel) }\end{array}$ & 0.110 & 0.048 & 0.039 & 0.066 \\
\hline $\begin{array}{l}\text { 410-MN: } 1.8 \\
\text { 420-MN: } 2.8 \\
\text { (stainless } \\
\text { steel) }\end{array}$ & 0.042 & 0.016 & 0.012 & 0.023 \\
\hline $\begin{array}{l}\text { 410-MN: } 1.7 \\
\text { 420-MN: } 1.7 \\
\text { (stainless } \\
\text { steel) }\end{array}$ & 0.116 & 0.012 & 0.008 & 0.045 \\
\hline $\begin{array}{l}\text { 321-MN: } 1.4 \\
\text { 304-MN:1.9 } \\
\text { (stainless } \\
\text { steel) }\end{array}$ & 0.017 & 0.007 & 0.006 & 0.010 \\
\hline Monel 400 & 0.356 & 0.035 & 0.027 & 0.139 \\
\hline
\end{tabular}

The concluded interpretation of the above results has been shown in Figure 2.

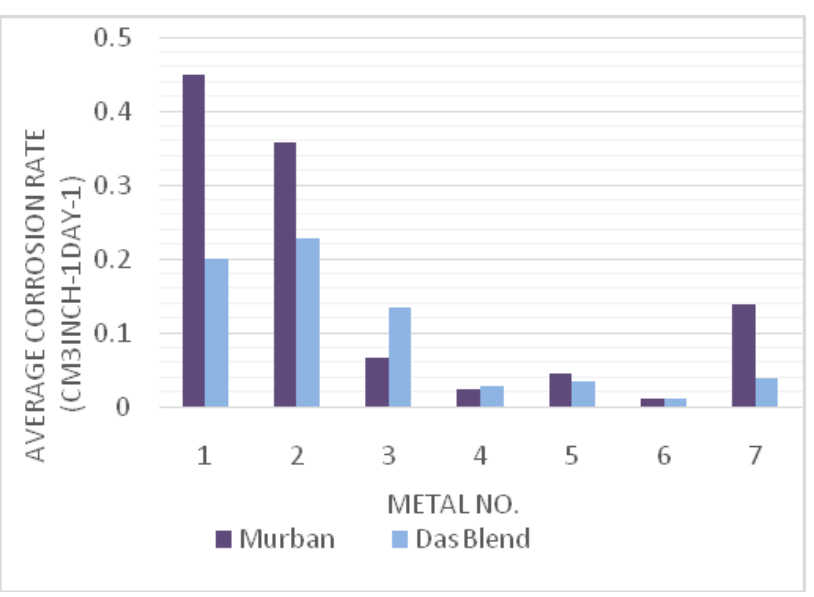

Figure 2 - Average corrosion rates of metals

According to the above graph that it can be concluded the higher corrosion rates from carbon steels, moderate corrosion rates from Monel metal and the relatively lower corrosion rates of stainless steels with respect to both Murban and Das Blend crude oils. When comparing with the corrosion rates of stainless steels the least corrosion rates were observed from 321-N: 1.4304-MN: 1.9 (stainless steel) with respect to both Murban and Das Blend crude oils which is having a chemical composition of $18 \%$ of chromium and $8.65 \%$ of nickel also a good enough combination for the formation of the selfcorrosive protection film on the metal surfaces itself because the chromium and nickel are presence with the sufficient amounts [1, 3-6].
Table 5 - Corrosion rates of metals in Das Blend, $\mathrm{cm}^{3} /$ (inch day)

\begin{tabular}{|l|c|c|c|c|}
\hline \multirow{2}{*}{ Metal } & \multicolumn{3}{|c|}{ Number of days } & \multirow{2}{*}{ Average } \\
\cline { 2 - 4 } $\begin{array}{l}\text { carbon steel } \\
\text { (high) }\end{array}$ & 0.350 & 0.225 & 0.025 & 0.200 \\
\hline $\begin{array}{l}\text { carbon steel } \\
\text { (medium) }\end{array}$ & 0.481 & 0.141 & 0.059 & 0.227 \\
\hline $\begin{array}{l}\text { carbon steel } \\
\text { (mild steel) }\end{array}$ & 0.163 & 0.141 & 0.101 & 0.135 \\
\hline $\begin{array}{l}\text { 410-MN: } 1.8 \\
\text { 420-MN: } 2.8 \\
\text { (stainless } \\
\text { steel) }\end{array}$ & 0.044 & 0.034 & 0.006 & 0.028 \\
\hline $\begin{array}{l}\text { 410-MN: } 1.7 \\
\text { 420-MN: } 1.7 \\
\text { (stainless } \\
\text { steel) }\end{array}$ & 0.054 & 0.035 & 0.016 & 0.035 \\
\hline $\begin{array}{l}\text { 321-MN: } 1.4 \\
\text { 304-MN:1.9 } \\
\text { (stainless } \\
\text { steel) }\end{array}$ & 0.023 & 0.007 & 0.003 & 0.011 \\
\hline Monel 400 & 0.062 & 0.038 & 0.016 & 0.038 \\
\hline
\end{tabular}

When comparing the corrosion rates of metals in both crude oils four types of metals showed their higher corrosion rates in Murban crude oil since the other three types of metals were showing their higher corrosion rates in Das Blend crude oil. According to such observations it is possible to suggest the higher corrosive impact of salts on the metallic corrosion when comparing with the other corrosive compounds. Although it is better to recommend some advanced corrosion rate analysis instrument such as electrical instrument simultaneously with the weight loss method and also investigations of the impact of some more corrosive compounds in various temperature and other supplementary conditions for future works [6-15].

According to the above results the variations of the corrosion rates of metals with respect to the immersion time periods in both crude oils have been interpreted in Figures 3, 4 .

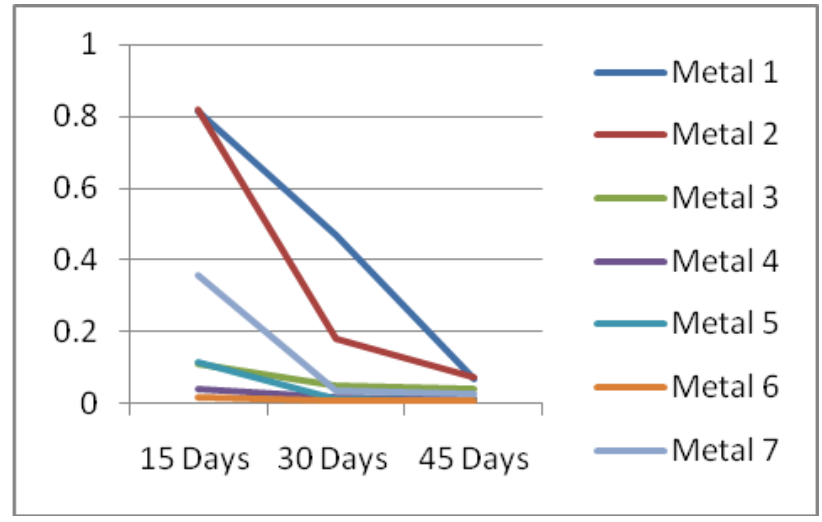

Figure 3 - Variations of the corrosion rates of metals in Murban 


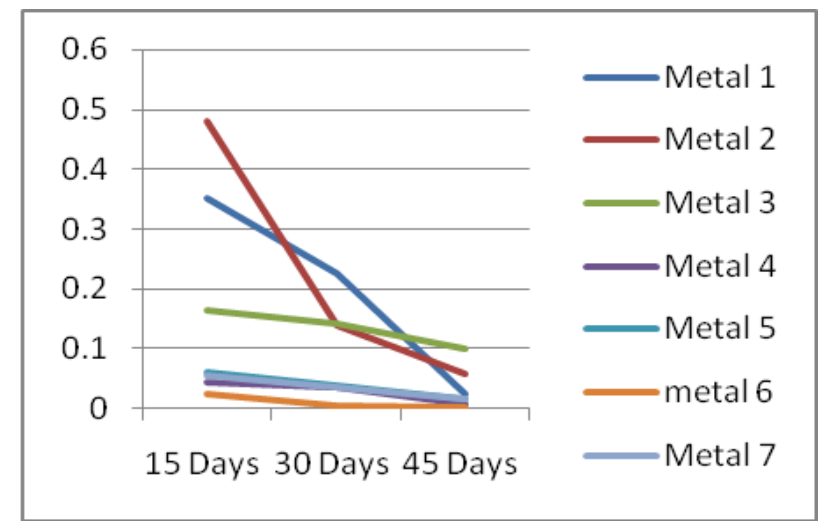

Figure 4 - Variations of the corrosion rates of metals in Das Blend

The above corrosion curves showed some similar distributions of the corrosion rates of metals with the exposure time by following the inversely proportional relationship between the two parameters of the corrosion rate and the exposure time as explained under the weight loss method $[9,10]$.

According to the explanations of the material and chemical engineering the reductions of the corrosion rate with the exposure time period is happened as the results of the generating corrosion barrio from the formerly formed corrosion compounds on the metal surfaces that the continuously formation of the corrosion in the same rate ahead.

Regarding the analysis of the corroded metal surfaces through the 400X lens of an optical microscope there were observed few of various results that similar with the explanations in the corrosion processes and some sort of different compounds as well. The most highlighted and recognizable corrosion compounds have been interpreted in Figure 5.

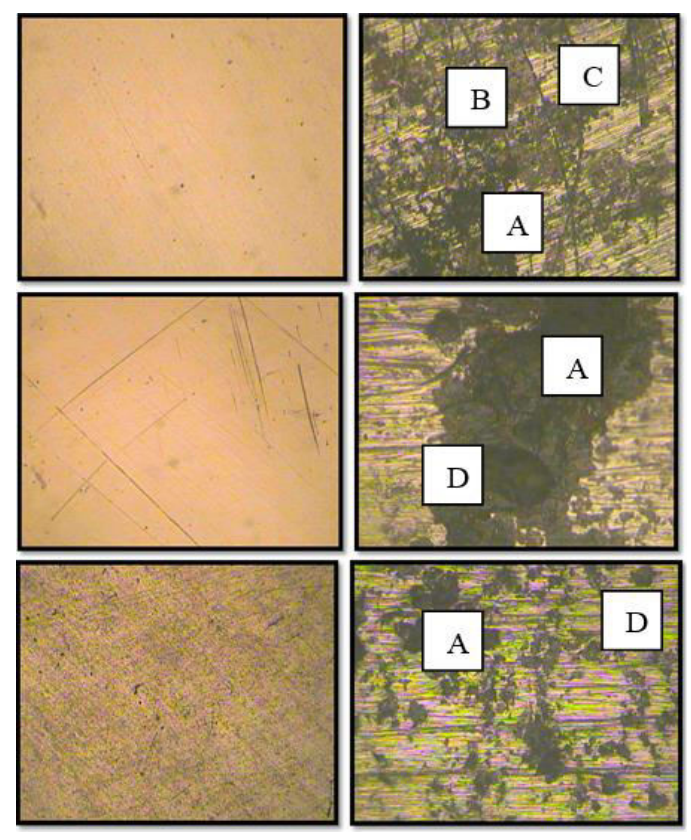

Figure 5 - Corroded metal surfaces:

A - ferrous sulfide (FeS); B - ferrous oxide $\left(\mathrm{Fe}_{2} \mathrm{O}_{3}\right)$; $\mathrm{C}$ - corrosion cracks; $\mathrm{D}$ - pitting corrosion
Among the various observations some of distinguished features have been emphasized with their physical appearances in Table $6[1,3,6]$.

Table 6 - Visible appearemces of the corrosion compounds

\begin{tabular}{|l|l|l|}
\hline Compound & \multicolumn{1}{|c|}{ Appearances } & Observations \\
\hline $\mathrm{FeS}$ & $\begin{array}{l}\text { black, brownish black, } \\
\text { property of powder, } \\
\text { pitting, cracks }\end{array}$ & $\begin{array}{l}\text { observed most of } \\
\text { features in each } \\
\text { metal piece }\end{array}$ \\
\hline $\mathrm{Fe}_{2} \mathrm{O}_{3}$ & rusty color & Observed rarely \\
\hline $\mathrm{CuS}$ & $\begin{array}{l}\text { dark indigo / dark } \\
\text { blue, property of } \\
\text { powder }\end{array}$ & unable to specify \\
\hline
\end{tabular}

According to the observations and the identifications of the microscopic analysis results basically it is possible to conclude the formations of the ferrous sulfides $(\mathrm{FeS})$ in most of occasions same as the explanations of under the theoretical conditions, rarely formations of ferrous oxides $\left(\mathrm{Fe}_{2} \mathrm{O}_{3}\right)$ due to the presence of both water and oxygen in little amounts, corrosion cracks and some pitting on the metal surfaces due to the decay of metals into crude oils. As the uncertain observations some corrosion compounds were identified that similar with the ferrous sulfides with the visible features and most probably it might be copper sulfide $(\mathrm{CuS})$ although it is impossible to conclude as $\mathrm{CuS}$ only having the visible features $[1,3-6,13]$. Therefore, it is better to recommend some compositional analysis of the corrosion compounds by an advanced analytical method such as X-ray diffraction (XRD) for better analysis.

According to the analysis of the decay of metallic elements from metals into crude oils by the atomic absorption spectroscopy (AAS) the obtained results have been interpreted in Table 7.

Table 7 - Decayed metallic concentrations into crude oils / ppm

\begin{tabular}{|l|l|c|c|}
\hline \multicolumn{1}{|c|}{ Metal } & Crude oil & $\mathrm{Fe}$ & $\mathrm{Cu}$ \\
\hline \multirow{3}{*}{ Carbon Steel } & Murban & 0.47 & - \\
\cline { 2 - 4 } & Das Blend & 1.10 & - \\
\hline \multirow{2}{*}{ Carbon Steel } & Murban & 0.54 & - \\
\cline { 2 - 4 } & Das Blend & 0.02 & - \\
\hline \multirow{2}{*}{ 410-MN: 1.8} & Murban & -0.08 & - \\
\cline { 2 - 4 } 420- MN: 2.8 & Das Blend & -0.48 & - \\
\hline \multirow{2}{*}{ 410-MN: 1.7} & Murban & -0.65 & - \\
\cline { 2 - 4 } 420-MN: 1.7 & Das Blend & -0.78 & - \\
\hline \multirow{2}{*}{ 321-MN:1.4 } & Murban & -0.71 & - \\
\cline { 2 - 4 } 304-MN:1.9 & Das Blend & -0.79 & - \\
\hline Monel 400 & Murban & -0.44 & - \\
\cline { 2 - 4 } & Das Blend & -0.17 & - \\
\cline { 2 - 4 } & Murban & - & 10.47 \\
\cline { 2 - 4 } & Das Blend & - & 9.49 \\
\hline
\end{tabular}

Brief conclusions of above results have been shown in Figures 6, 7. 


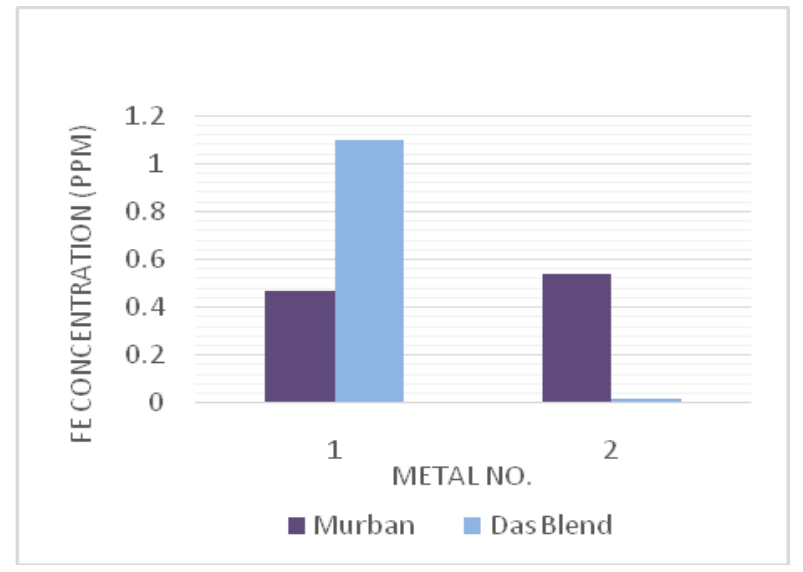

Figure 6 - Decayed ferrous concentrations into crude oils

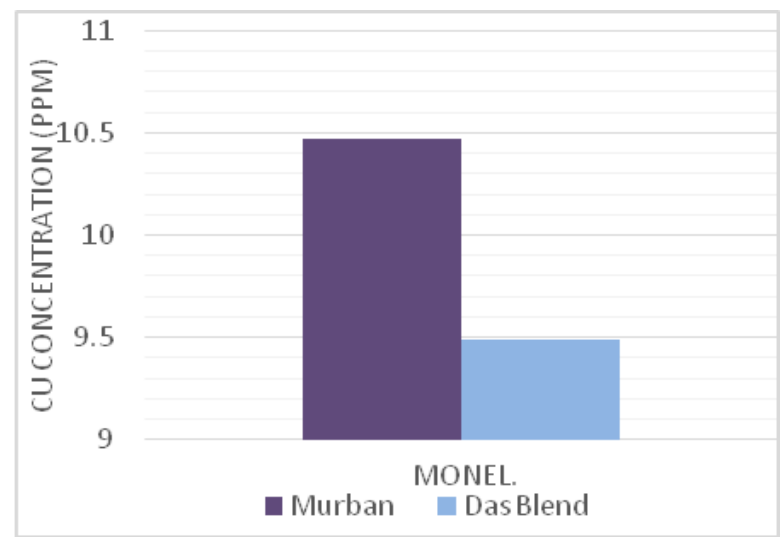

Figure 7 - Decayed copper concentrations into crude oils

Basically with the above graphs that there can be seen significant decays of copper from Monel metal which showed some intermediate corrosion rate, higher decays of ferrous from carbon steels which showed the highest corrosion rates and it was not observed any decay of neither copper nor ferrous from any stainless steel into crude oils while the immersion which showed least corrosion rates. According to the reasonable explanations that it is possible to explain with the electron repulsive theory that after formations of the corrosion compounds such corrosion compounds tend to be removed from the metal surfaces either partially or completely from the metal surfaces due to the repulsive and attractive forces between the successive electrons and protons of the relevant compounds $[1,3,5,6]$. Therefore, the decayed metallic compounds from metals into crude oil may be happened simultaneously with the process of corrosion.

According to the analysis of the variations of the initial hardness of the metals due to the corrosion by the Vicker's hardness tester the obtained results have been interpreted in Figures 8, 9.

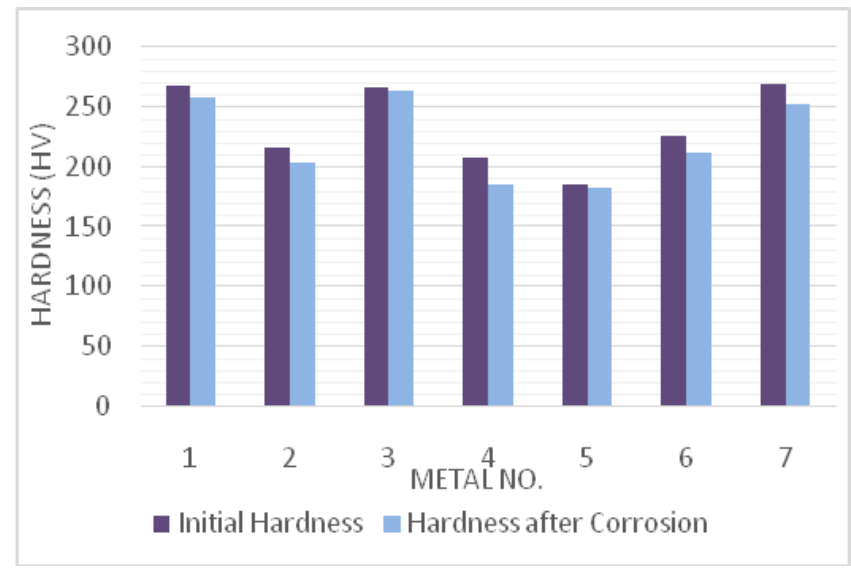

Figure 8 - Variations of the initial hardness of metals due to the corrosion in Murban

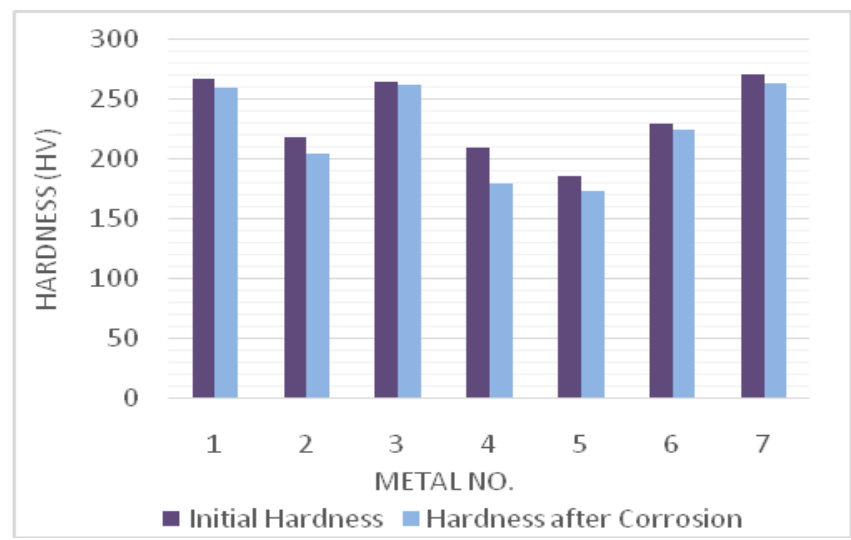

Figure 9 - Variations of the initial hardness of metals due to the corrosion in Das Blend

The above results showed slight reductions of the initial hardness of most of metals after the formations of the corrosion. This incident is possible to explain with the electron repulsive concept and heterogeneity $[1,3,5,6]$ :

1) due to the repulsive and attractive forces between successive electrons and protons it is possible to be formed some uncertain conditions on the metal surfaces;

2) due to the heterogeneity of the corroded metal surfaces due to the contamination with the corrosion compounds.

\section{Conclusions}

According to the results of the entire results of the research there were investigated the lower corrosion rates from stainless steels which are having at least $12 \%$ of chromium with sufficient amount of nickel because of the nickel chromium corrosive protection film, relatively higher corrosive impact from salts when comparing with the corrosive impact of other corrosive compounds, formations of $\mathrm{FeS}, \mathrm{Fe}_{2} \mathrm{O}_{3}$, corrosion cracks and cavities on the metal surfaces as the corrosion compounds, significant decay of copper and ferrous from some of metals into crude oils and small reductions of the initial hardness of most of metals due to the corrosion. 


\title{
5 Acknowledgments
}

The important guides of the supervisor and technical supports from the laboratory staff are admired prestigiously.

\section{References}

1. Khana, O. P. (2009). Materials Science and Metallurgy. New Delhi: Dhanpet Rai and Sons Publication.

2. Fahim, M. A., Alsahhaf, T. A., Elkilani, A. (2010). Fundamentals of Petroleum Refining. Elsevier, 516, doi: 10.1016/c2009-016348-1.

3. Calister, W. D. (2003). An Introduction of Materials Science and Engineering. New York: John Wiley and Sons, 820.

4. Davis, M. E., Davis, R. J. (2003). Fundamentals of Chemical Reaction Engineering. New York: McGraw-Hill.

5. Singh, R. (2006). Introduction to Basic Manufacturing Process and Engineering Workshop. New Delhi: New Age International Publication, 475.

6. Bolton, W. (1993). Engineering Materials Technology. Elsevier,468, doi: 10.1016/c2013-0-04622-1.

7. Ajimotokan, H. A., Badmos, A. Y., Emmanuel, E. O. (2009). Corrosion in petroleum pipelines. New York Science Journal, Vol. 2 (5), pp. 36-40.

8. Speight, J. G. (1999). The Chemistry and Technology of Petroleum. Boca Raton, 934. doi: 10.1201/9780824742119.

9. Afaf, G. A. (2007). Corrosion Treatment of High TAN Crude. Khartoum.

10. Okpokwasili, G. C., Oparaodu, K. O. (2014). Comparison of percentage weight loss and corrosion rate trends in different metal coupons from two soil environments. International Journal of Environmental Bioremediation and Biodegradation, Vol. 2 (5), pp. 243-249.

11. Usman, A. D., Okoro, L. N. (2015). Mild steel corrosion in different oil types. International Journal of Scientific Research and Innovative Technology, Vol. 2 (2), pp. 9-13.

12. Ahmed, I. M., Elnour, M. M., Ibrahim, M. T. (2014). Study the effects of naphthenic acid in crude oil equipment corrosion. Journal of Applied and Industrial Sciences, Vol. 2 (6), pp. 255-260.

13. Rickard, D., Luther, G. W. (2007). Chemistry of iron sulfides. Chemical Reviews, Vol. 107 (2), pp. 514-562. doi: 10.1021/cr0503658.

14. Fang, H., Nesic, S., Young, D. (2008). Corrosion of mild steel in the presence of elemental sulfur. International Corrosion Conference and Expo.

15. Bota, G. M., Nesic, S., Qu, D., Wolf, H. A. (2010). Naphthenic acid corrosion of mild steel in the presence of sulfide scales formed in crude oil fractions at high temperature. International Corrosion Conference and Expo.

\section{Загальні особливості металевої корозії у сирій неочищеній нафті}

\author{
Алувіхара С. ${ }^{1}$, Премахандра Дж. К. ${ }^{2}$
}

\footnotetext{
${ }^{1}$ Кафедра хімічного і технологічного машинобудування, Університет м. Параденія, 20400, м. Параденія, Шрі-Ланка;

${ }^{2}$ Кафедра хімічного і технологічного машинобудування, Університет Моратува, 10400, м. Катубедда, Шрі-Ланка
}

Анотація. Сира нафта увосновному складається 3 різних вуглеводнів, маючи у своєму складі деяку кількість корозійних сполук сірки, нафтенових кислот і солей. У даному дослідженні досліджувався вплив корозійних властивостей на корозію семи різних типів чорних металів. У основі методології досліджень обране визначення основних корозійних властивостей двох різних видів сирої нафти і хімічного складу семи обраних типів металів. Результати вимірювань проаналізовані за стандартною методологією із застосуванням запропонованих інструментів. Швидкість корозії металів визначався методом відносної втрати ваги після заданих періодів занурення та одночасно з мікроскопічним аналізом корозії металевих поверхонь. Крім того, розподіл концентрації металевих включень у сирій нафті був проаналізований методом атомно-абсорбційної спектроскопії, а вплив корозії на початкову твердість металів вимірювався за методом Віккерса. У результат і всього дослідження спостерігалися відносно низькі швидкості корозії нержавіючих сталей 3 вмістом принаймні 12 \% хрому і деякої кількості нікеля. Також спостерігався більш високий корозійний вплив солей на корозію з утворенням хімічних сполук $\mathrm{FeS}, \mathrm{Fe}_{2} \mathrm{O}_{3}$, а також корозійні тріщини і виразки на металевих поверхнях.

Ключові слова: сира нафта, складові корозії, метали, втрати ваги, розкладання, корозія. 